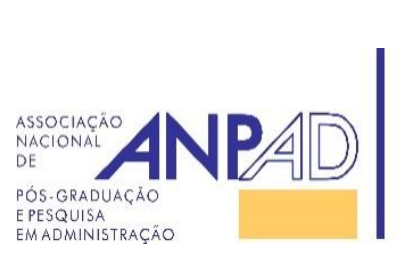

Available online at http://www.anpad.org.br/bar

BAR, Rio de Janeiro, v. 14, n. 1, art. 3, e160076, 2017

\title{
Are Country and Size Risks Priced in the Brazilian Stock Market?
}

\author{
Antonio Zoratto Sanvicente ${ }^{1}$ \\ Hsia Hua Sheng ${ }^{2,3}$ \\ Luiz Felipe Poli Guanais ${ }^{1}$
}

Fundação Getulio Vargas - Escola de Economia de São Paulo ${ }^{1}$ Fundação Getulio Vargas - Escola de Administração de Empresas de São Paulo ${ }^{2}$ Universidade Federal de São Paulo - Escola Paulista de Política, Economia e Negócios ${ }^{3}$

Received 3 August 2016; received in revised form in 20 February 2017 (this paper has been with the authors for two revisions); accepted in 21 February 2017; first published online 13 March 2017. Editor's note. Ricardo Pereira Câmara Leal served as Associate Editor for this article. 


\begin{abstract}
When estimating a firm's cost of equity for valuation and other purposes in emerging markets without (or with only partial) capital market integration, many practitioners include a premium for country risk. In principle, the inclusion of such a risk factor would be justified if the particular country of interest was not sufficiently integrated into the global capital market. Initially, the paper measures and tests the degree of integration for the Brazilian market and does not reject the hypothesis of integration. The paper then tests directly the relevance of country risk premium in individual stocks' expected returns in the Brazilian market. Monthly data for the stocks of 57 of the most actively traded, non-financial firms, over the 2004 to 2014 period are used, using EMBI (Emerging Markets Bond Index) as a proxy for country risk, and this is found not to be significant. Finally, a premium for the size factor, also commonly used by practitioners, is also tested. Although it is found to be significant, the premium is negative, in contrast with current practice, which entails the addition of a positive premium to the required returns on small stocks. The inclusion of both a country risk and a size premium, in addition to the market portfolio risk premium, corresponds to the use of the Goldman Sachs model, as proposed by Mariscal and Lee (1993).
\end{abstract}

Key words: capital market integration; country risk; size risk; systematic risk. 


\section{Introduction}

It certainly goes without saying how crucial the estimation of a firm's cost of equity is, especially for practical purposes - for equity and firm valuation in mergers and acquisitions, security analysis for investment recommendation purposes, for the determination of value creation by managers, and various other essential corporate finance decisions.

The starting point in most of the current practice is to begin with the Sharpe-Lintner-Mossin (SLM) version of the capital asset pricing model (CAPM), in which values for the rate of return on a proxy for the risk-free asset and a premium for exposure to market portfolio risk would be sufficient, including an estimate for the asset's degree of exposure (beta).

However, in many cases practitioners add premiums for other risk factors, for at least two reasons: (a) they do not believe the SLM version of the CAPM is valid, as indicated by the Fama and French (1992) results, or (b) they feel the need to adjust the SLM version of the CAPM for conditions in the specific market in which an investment is to be evaluated. For the first reason, a premium for the companies' size is frequently added (following the conclusions of Fama \& French, 1992). An example of the second reason is the addition of a premium for country risk, in the belief that the country's market is not sufficiently integrated into the world market, so that this country risk would not be diversifiable, from the perspective of an international investor. This procedure is reported through a survey by Keck, Levengood and Longfield (1998).

The so-called Goldman Sachs model, attributed to Mariscal and Lee (1993), consists in the use of proxies from a developed, integrated market, such as that of the United States, for both the risk-free asset (e.g., US Treasury bonds) and the market portfolio (e.g., the S\&P500 index). With such data, a U.S. investor would evaluate investments in her domestic market. However, if the investor was evaluating an investment opportunity, say, in Brazil, the Goldman Sachs model would recommend the addition of a premium for Brazil risk (e.g., the EMBI+ Brazil index), measuring the spread between the yields on Brazilian sovereign bonds and US Treasury bonds.

Even though it is not clear that the evaluation is being performed for the benefit of an international investor, local market evaluations make frequent use of the Goldman Sachs model. In a survey of 52 valuation reports for going-private purchase offers, as required by the corresponding Brazilian regulation, covering the 2008-2013 period, Sanvicente (2015) finds that in all reports an adjustment is made for country risk, using, in over $50 \%$ of the cases, the EMBI+ published by JP Morgan. In turn, the risk-free asset is proxied by 10- or 30-year US Treasury bonds, and the market portfolio is represented by the S\&P500 index, the market risk premium being measured with average historical returns. Hence, it can be claimed that at least $50 \%$ of these particular applications of cost of equity estimation methods make explicit use of the Goldman Sachs model. An also frequent procedure is to add a positive premium for a size factor, particularly when the firm being evaluated is classified, somewhat arbitrarily, as a small firms.

The objective of the present paper is, therefore, to determine the empirical relevance of the Goldman Sachs model to the estimation of the cost of equity for the Brazilian market. This is accomplished both directly, through a test of the significance of a country risk premium for equity expected returns in a factor model, and indirectly, by testing whether the Brazilian market is partially or fully integrated into the world market, using the incremental risk measure proposed by Keck et al. (1998). The paper also tests the significance of the size premium in a multifactor model, as in Fama and French (1992) for the equities' expected returns. Other risk factors considered in the Fama and French (1992) 3-factor model (the value-growth factor) or in the Fama and French (2015) 5-factor model (valuegrowth, investment, and profitability) are not tested in the present paper, since our direct goal is to test the Goldman Sachs model as currently used in Brazil, that does not include the Fama-French factors identified within the parentheses. 
The paper is structured in this manner: following this Introduction, a discussion of the relevant literature is presented, the methodology used for both tests is explained, data definitions and sources are provided, results are displayed, and the paper then is concluded.

\section{Review of Literature}

\section{Country risk and market integration}

Country risk is an important factor in a cross-border investment, especially in a not fully integrated market. One of the basic issues in the choice of a model as a basis for the estimation of cost of equity and discount rates in general, when dealing with investments outside the domestic economy, is the perception of how integrated the particular overseas market is, and whether one should adjust a basic model for non-diversifiable risks, such as country risk, or similar manifestations of emerging market risks, such as political or currency risk.

It is reported in the literature that investors tend to adjust their valuation methodology as a function of their perception of how much the particular market is integrated into the world market (Keck, Levengood, \& Longfield, 1998). It is also emphasized that it is possible to construct a parallel between cost of equity computation methods and a market's degree of integration (Fuenzalida \& Mongrut, 2010; Harvey, 2005; Stulz, 1999).

For fully integrated markets, Stulz (1999) argues that firms should adopt a discount rate treating them as part of the world stock portfolio. Global portfolio diversification would then lead to risk reduction and hence to the lowering of required returns. In this case, home investors can freely invest in foreign assets, and international investors can invest in domestic assets (Bekaert, Harvey, \& Lundblad, 2003). As a consequence, if markets were fully integrated, country risk would be irrelevant in the estimation of the cost of equity, since it could be eliminated via diversification (Harvey, 2005).

It may also be observed that the covariance of returns with a global factor may have low explanatory power for expected returns in a segmented market. This dynamic will change when an economy moves from segmented to integrated. Expected returns, return volatilities and correlations with major global market indices would be affected in that process (Bekaert \& Harvey, 1995; Bekaert, Harvey, \& Lumsdaine, 2002; Errunza \& Miller, 2000; Henry, 2000).

\section{Country risk and global diversification}

Global diversification can lower the cost of equity. Henry (2000) observes that a country's market index, when the economy is in a process of liberalization, achieves abnormal returns of approximately $3.3 \%$ on a monthly basis (in real US dollar terms) for eight months since the inception of liberalization policies. This result is consistent with the contention that liberalization policies help to lower the cost of equity level in a given country, since international risk diversification now becomes possible (Bekaert et al., 2002; Errunza \& Miller, 2000; Henry, 2000; Stulz, 1999).

Despite such benefits from international portfolio diversification, in practice investors have preferences for domestic assets. This is the so-called home bias, leading agents to invest in the assets that are more familiar to them, ignoring the principles of portfolio theory, even if markets were fully integrated (Huberman, 2001). In other words, people invest disproportionately more in domestic assets than in foreign assets (Sercu \& Vanpée, 2007). For example, many emerging-market investors are barred from investing in foreign company shares, due to government regulation and/or constraints imposed by their investing partners. Therefore, even when there is market integration, insufficiently diversified portfolios may result from purposeful actions, making country risk relevant. 


\section{Country risk and cost of equity models}

There are different equity pricing models. They may be classified into three main segmentation/integration categories: segmented, fully integrated, and partially integrated markets (Bekaert \& Harvey, 1995). It is possible to associate cost of equity estimation methods with a market's degree of integration (Fuenzalida \& Mongrut, 2010; Pereiro, 2001; Stulz, 1999), as is illustrated in Table 1.

Table 1

Cost of Equity and Capital Market Integration

\begin{tabular}{lllll}
\hline $\begin{array}{l}\text { Cost of equity } \\
\text { estimation method }\end{array}$ & $\begin{array}{l}\text { Market portfolio } \\
\text { proxy }\end{array}$ & $\begin{array}{l}\text { Systematic risk } \\
\text { measure }\end{array}$ & References & $\begin{array}{l}\text { Degree of market } \\
\text { integration }\end{array}$ \\
\hline Global CAPM & MSCI World Index & Global beta & $\begin{array}{l}\text { Solnik (1974); Stulz } \\
(1995)\end{array}$ & Fully integrated \\
\hline $\begin{array}{l}\text { Goldman Sachs } \\
\text { model }\end{array}$ & S\&P 500 & S\&P 500 beta & $\begin{array}{l}\text { Mariscal and Lee } \\
(1993)\end{array}$ & Partially integrated \\
\hline Local CAPM & Local market index & Local index beta & $\begin{array}{l}\text { Sharpe (1964); } \\
\text { Lintner (1965); } \\
\text { Mossin (1966) }\end{array}$ & Segmented \\
\hline
\end{tabular}

Table 1 shows that, as pointed out by Keck et al. (1998), with greater uncertainty and market complexity in not fully integrated markets, investors tend to resort to multifactor models, such as the Goldman Sachs version, and to the addition of ad hoc risk premiums.

For the firms with access to the global stock market, the use of the Sharpe-Lintner-Mossin CAPM that presumes market segmentation (Bekaert \& Harvey, 1995) will tend to overestimate the cost of equity, since diversifiable risks in a local market investment could now be diversified internationally (Stulz, 1999).

Thus, Stulz (1999) proposes a Global CAPM approach, in which any investment is part of a global portfolio, using a global market index such as the MSCI World Index as a proxy for the market portfolio.

However, when the Global CAPM is used for stocks in emerging markets, and a regression is run against a global market proxy such as the MSCI World Index, betas are negative or close to zero (Harvey, 1995). Therefore, given the low correlations between many emerging markets and developed markets, in addition to the preponderance of local factors as explanations for expected returns, the Global CAPM should not be used when investments are contemplated in less than fully integrated markets. Harvey (1995) points out that when one uses an asset pricing method based on the Global CAPM, as in Stulz (1999), one is assuming that the market examined is fully integrated into the world market. The rejection of such a global model, therefore, could be explained by the failure of the full market integration assumption.

One adaptation that is widely used by many investment banks and consulting firms is the Goldman Sachs Model, developed by Mariscal and Lee (1993). It is one of the first models to assume partial market integration, especially in emerging markets (Fuenzalida \& Mongrut, 2010).

In the Goldman Sachs model, a regression is run between stock returns and returns on the S\&P 500. The betas thus estimated are multiplied by the risk premium on the S\&P 500 index. Finally, a country risk premium is added, in an ad hoc fashion, to correct for an allegedly low cost of equity. Such a premium can be based on the Emerging Markets Bond Index Plus (EMBI+), computed by JP Morgan, measuring the spread between yields on sovereign debt instruments issued by the country of interest, traded overseas, and yields on US Treasury securities with similar time to maturity (Zenner, Hill, Clark, \& Mago, 2008). 
Sanvicente (2015) tested the significance of country risk for observed returns, using a sample of 204 firms in the Brazilian market. Observing that the performance of the local proxy for the market portfolio is already affected by country risk, the addition of a country risk premium would then be unnecessary, a result that would provide support for the use of Local CAPM when assessing the cost of equity in Brazil, even from the viewpoint of international investors.

According to Keck et al. (1998), global market integration implies that investors, be they local or international, should use Global CAPM to estimate the cost of equity. For those investors in relatively segmented markets, however, the use of Local CAPM would be justified.

\section{Methodology}

In this section, we initially provide information on how we are testing for capital market integration, a necessary condition for the economic relevance of a country risk premium. Then we test for the significance of a country risk premium directly, using regression methods with panel data. Finally, we test for the significance of a premium for the size factor, since many practitioners believe this is an important risk to be considered in the estimation of asset expected returns.

\section{Testing for capital market integration}

We use our data to implement the Keck et al. (1998) proposal. Keck et al. (1998) argue that two hypothetical firms, with identical products, cash flows and capital structures, but located in different national markets, one fully integrated and the other partially integrated to the global economy, should have different expected returns.

The firm based in the partially integrated market, from an international investor's viewpoint, faces a risk pricing process which is distinct from that faced by the firm based in the fully integrated market. Thus, when one compares the expected returns for the two firms, their cost of equity models should be as follows.

For the firm located in a fully integrated market (Home market):

$$
E\left(r_{H}\right)=r_{f}+\left(b_{H L} \times b_{L h G}\right)\left[E\left(r_{G)-r_{f}}\right\rfloor\right.
$$

where $b_{\mathrm{HL}}$ is the slope of the regression of the integrated firm's returns against the returns on its home country's index. In turn, $b_{\mathrm{LhG}}$ is the slope of the regression of the fully integrated market's index against the returns on a global market index.

For the firm located in a partially integrated market (Away market):

$$
E\left(r_{A}\right)=r_{f}+\left(b_{A L} \times b_{L a G}\right)\left\lfloor E\left(r_{G}\right)-r_{f}\right\rfloor
$$

where $b_{\mathrm{AL}}$ is the slope of the regression of the partially integrated firm's returns against the returns on its own local market index, whereas $b_{\mathrm{LaG}}$ is the slope of the regression of the local market index returns against those of the global market index.

If both markets were fully integrated into the world market, the expected returns for both firms would be identical, so that ( $b_{H L} \times b_{\text {Lhg }}$ ) would be equal to $\left(b_{A L} \times b_{L a G}\right)$. For the firm located in the Away market, when it is not fully integrated, the cost of equity would be given by:

$$
E\left(r_{A}\right)=r_{f}+\left(b_{A L} \times b_{L a G}+b_{a}\right)\left\lfloor E\left(r_{G}\right)-r_{f}\right\rfloor
$$


with $b_{a}$ indicating the incremental risk associated with the fraction of the Away market's returns that co-vary with the global market, but not with the local market. Thus, risk in such market is priced differently, from the international investor's viewpoint.

The test proposed by Keck et al. (1998) identifies the incremental risk, interpreted as a proxy for market integration, with the use of regression betas in two distinct scenarios: in the first scenario, it is assumed that a particular firm is located in an integrated market, and in the second scenario one uses the market in which it is in fact located (Brazil, in this case).

The proxy chosen for an integrated market was the United States, and the market portfolio was represented by the S\&P 500. For Brazil, the market proxy was the IBrX 100 index. Finally, for a global market portfolio, the proxy used was the MSCI World Index.

Given the sample selection procedure for each year, betas were first estimated, with historical excess returns over a 60-month period, provided at least 36 months were available. Thus, two betas are calculated for each firm: one for the integrated market (US), and the other for the Brazilian market.

The incremental risk measure $\left(b_{a}\right)$ was assessed for each sample year and for the 2004-2014 period, resulting in annual and full-period averages. For each of those results a one-tail test of the null hypothesis of a zero mean was performed, against the alternative hypothesis that the incremental risk measure is positive, indicating less than full integration of the Brazilian market.

\section{Testing for the significance of country risk premium}

The methodology described in section Testing for capital market integration is concerned with testing for market integration. In turn, the methodology described in section Testing for the significance of country risk premium is concerned with assessing the significance of country risk (and later size risk) in the determination of individual firms' expected returns. The dependent variable is now represented by expected returns for individual stocks, as extracted from current stock market prices, as opposed to historical returns.

As proposed in Harris, Marston, Mishra, and O'Brien (2003), Sanvicente and Minardi (1999), and Sanvicente and Carvalho (2013), expected returns, as a measure of an investment's opportunity cost, are best extracted from the corresponding asset's intrinsic value, defined as the present value of all payments to the investor, including dividends and terminal selling price, discounted at a risk-adjusted interest rate. In equilibrium, current market price would reflect intrinsic value estimates. Assuming that dividends grow perpetually at a constant rate, the stock price may be written as:

$$
P=D_{0}(1+\mathrm{g}) /(r-\mathrm{g})
$$

where:

- $\mathrm{D}_{1}=\mathrm{D}_{0}(1+\mathrm{g})=$ next period's expected dividend

- $\mathrm{r}=$ rate of return required by the investor

$\mathrm{g}=$ rate of growth of dividends

Proposed by Gordon (1959), the formula is known as the Constant Growth Discounted Dividend Model. It allows us to extract the stock's required rate of return (r) from a security traded at its intrinsic value as:

$$
r=\left(D_{1} / P\right)+g=\text { dividend yield }+ \text { expected dividend (and earnings) growth }
$$

This is implemented in the present paper in contrast with the usual practice of using estimates of risk premiums based on historical returns. Fama and French (2002) favor the use of dividend and expected growth fundamentals in the estimation of expected returns, as opposed to the use of average 
historical returns as a proxy for expected returns, adding that the standard deviation of expected market risk premiums obtained with the Discounted Dividend Model is less than half the standard deviation resulting from the use of historical returns.

Elton (1999) claims that the use of historical returns as a proxy for expected returns is based on the belief that informational surprises that are capable of altering expectations would tend to cancel each other over time and, therefore, average historical returns would be an unbiased estimate of expected returns. However, he shows that an inertial effect may result when large and persistent surprises are possible. Their cumulative effect could be sufficiently large to invalidate the use of historical returns as proxies for expected returns.

Testing most versions of the CAPM and other expected return models involves a two-stage procedure. In the first stage, time series regressions are used for estimating betas for the various risk factors contemplated; the second stage consists in using such estimated betas as predictors in crosssectional regressions (Elton, Gruber, Brown, \& Goetzmann, 2006).

The paper first calculates betas for the risk factors considered, and then regresses the implied expected returns against the first-stage betas.

In order to assess the significance of a country risk premium for Brazilian stocks, initially stocks' excess returns were regressed against S\&P 500 excess returns and the EMBI+ Brazil series to obtain estimates for betas for each year. Each regression used the previous 60 months of data, when available.

Subsequently, the estimated betas were used as explanatory variables in panel data regressions. Since data were not available for all sample firms in every year, an unbalanced panel was used ${ }^{(1)}$. The analysis is performed for the 2004-2014 period.

The following specification was used:

$$
R_{i t}=\gamma_{0}+\gamma_{1} \beta_{1 \mathrm{it}}+\gamma_{2} \beta_{2 \mathrm{t}}+\eta_{\mathrm{it}}
$$

where:

- $\mathrm{R}_{\mathrm{it}}=$ excess expected returns for stock $\mathrm{i}$ in year $\mathrm{t}$.

- $\beta_{1 \mathrm{it}}=$ estimated beta for market risk, for stock $\mathrm{i}$ in year $\mathrm{t}$, obtained by multiple regression of past observed excess returns against excess returns on the market index (the S\&P 500) and the country risk indicator (EMBI+ Brazil).

- $\quad \beta_{2 i t}=$ estimated beta for country risk, for stock $\mathrm{i}$ in year $\mathrm{t}$, resulting from the same multiple regression with the stock's excess expected returns, the excess returns on the proxy for the market portfolio (the S\&P 500), and the country risk index.

Even though the Hausman test did not reject the random effects model as a null hypothesis, the fixed effects model was used. In order to account for sample firm heterogeneity, equation (6) was estimated with cross-section fixed effects. Rejection of the null hypothesis in the Hausman test indicates that the main assumption of the random effects model, that is, that the unobserved effect is not correlated with the explanatory variables is not true. This means that the fixed effects estimator should be used. However, even when the Hausman test fails to reject the null hypothesis, it is possible to use the fixed effects model. In this case, the estimator is consistent, but it is less efficient than the random effects estimator.

\section{Testing for the incremental size factor premium}

We also assess the significance of a multifactor model that comprises both the country risk premium factor and the size premium factor, as in Fama and French (1992). For the analysis of the size premium, we used the small minus big factor (SMB) provided by the Nefin Center at the Department of 
Economics, University of São Paulo. The SMB factor is the return of a portfolio with long positions in stocks with low market capitalizations (small) and short positions in stocks with high market capitalization (big).

Every January of each year, the eligible stocks were sorted according to their previous December market capitalizations and separated into 3 quantiles. The size portfolio returns were used, as with the country risk premium, in a time series regression. Stocks' excess returns were regressed against S\&P 500 excess returns, the EMBI+ Brazil series and SMB factor to obtain estimates for betas for each year. Subsequently, the estimated betas were used as explanatory variables in panel data regressions, estimated with cross-section fixed effects.

The following specification was used:

$$
R_{i t}=\gamma_{0}+\gamma_{1} \beta_{1 \mathrm{it}}+\gamma_{2} \beta_{2 \mathrm{t}}+\gamma_{3} \beta_{3 i \mathrm{t}}+\eta_{\text {it }}
$$

where:

- $\mathrm{R}_{\mathrm{it}}=$ excess expected returns for stock $\mathrm{i}$ in year $\mathrm{t}$.

- $\quad \beta_{\text {lit }}=$ estimated beta for market risk, for stock $\mathrm{i}$ in year $\mathrm{t}$, obtained by multiple regression of past observed excess returns against excess returns on the market index (the S\&P 500), the country risk indicator (EMBI+ Brazil) and the size premium.

- $\beta_{2 i t}=$ estimated beta for country risk, for stock $\mathrm{i}$ in year $\mathrm{t}$, resulting from the same multiple regression with the stock's excess expected returns, the excess returns on the proxy for the market portfolio (the S\&P 500), the country risk index and the size premium.

- $\beta_{3 i t}=$ estimated beta for size risk, for stock $i$ in year $t$, resulting from the multiple regression with the stock's excess expected returns, the excess returns on the proxy for the market portfolio (the S\&P 500), the country risk index and the size premium.

\section{Data and Data Sources}

The following data are used:

1. Monthly $\log$ returns of all stocks included in the $\operatorname{IBrX} 100$ index $^{(2)}$, from December 1999 to December 2014.

2. Annual dividends, in US dollars, as well as return on equity and payout ratios for all stocks included in the IBrX100 index, for the 2004-2014 period, as required by the calculation of expected returns according to the Constant Growth Discounted Dividend Model.

3. Monthly yields to maturity of 10-year US Treasury Bonds, as a proxy for the risk-free rate faced by international investors in emerging markets, as in Harris et al. (2003).

4. Monthly values of EMBI+ Brazil, a measure of the country's default risk on its sovereign debt, and the commonly used instrument for country risk.

5. Monthly returns on the S\&P500, as a proxy for the market portfolio, from December 1999 to December 2014.

6. Monthly returns on the MSCI World Index, as a proxy for the global market portfolio, also for the period from December 1999 to December 2014. 
7. Monthly returns on the $\operatorname{IBrX} 100$, as a proxy for the local market portfolio, used in the market integration tests, and also from December 1999 to December 2014.

8. Small minus big factor (SMB) provided by the Nefin Center at the Department of Economics, University of São Paulo, for each year.

Stock prices were collected from the Economática database, converted into US dollars and adjusted for dividends and stock splits. Annualized dividends, as well as values for return on equity and payout ratios were obtained from the IQ Capital Markets database.

Yields to maturity for 10-year US Treasury Bonds and the historical series for the S\&P500, MSCI World, EMBI+ Brazil and the IBrX 100 indexes were provided by Bloomberg.

The list of stocks considered in each year was defined according to the composition of IBrX 100 portfolio as of January of each year. The portfolio is rebalanced once a year as a function of each stock's liquidity and the market value of its free float.

The choice of the IBrX 100 index, instead of the Ibovespa, was based on the fact that in the former, market capitalization is used as a source of stock weights in the portfolio, instead of its share in total trading volume.

The initial sample was adjusted for the following criteria:

1. Firms for which dividend, return on equity or payout ratio data were not available in a given year, were excluded from that year's sample data.

2. Stocks without complete 12-month price series for a particular year were excluded from that year's sample data.

3. Stocks with less than 36 months of historical price series were ignored, since beta estimation required the use of at least 36 months of price data.

4. Only the most actively traded security for a given firm was used, when at least two security classes for the firm were contained in the index portfolio.

The effect was the reduction to the use of data for 57 firms, on average, over the 11-year period. The total number of observations was 628 firm-years.

\section{Results}

\section{Testing for market integration}

Using the methodology described in Keck et al. (1998), incremental risk was calculated for each sample firm in each year. It should be recalled that incremental risk was estimated by the difference between the betas calculated for each sample firm, in two different markets: the US, representing an integrated market, and the Brazilian market, for which the degree of integration is being assessed. The averages of the incremental risk measure were calculated across firms for each sample year and for the full period. The corresponding descriptive statistics are presented in Table 2 for the full 11-year period. 
Table 2

Descriptive Statistics: Incremental Risk (2004-2014)

\begin{tabular}{ll}
\hline Statistic & Value \\
\hline Average & -0.05 \\
\hline Standard error & 0.04 \\
\hline Median & 0.01 \\
\hline Standard deviation & 0.74 \\
\hline Variance & 0.52 \\
\hline Kurtosis & 50.01 \\
\hline Skewness & -5.05 \\
\hline Range & 10.56 \\
\hline Minimum & -7.59 \\
\hline Maximum & 4.17 \\
\hline Number of observations & 628 \\
\hline
\end{tabular}

Table 3 displays the sample averages obtained for incremental risk in each of the sample years, as well as the results of t-tests for the null hypothesis of full integration (incremental risk measure equals to zero, against the alternative of partial integration, under which the risk measure would be positive). This one-tail test is done at the $5 \%$ level, for which the critical t-value is approximately equal to 1.67 .

Table 3

Test of Integration with Annual Incremental Risk Measures, 2004-2014

\begin{tabular}{llll}
\hline Period & Average incremental risk & Degrees of freedom & t-statistic \\
\hline $2004-2014$ & -0.05 & 627 & -1.02 \\
\hline 2004 & -0.07 & 46 & -1.62 \\
\hline 2005 & 0.06 & 52 & 2.43 \\
\hline 2006 & -0.15 & 54 & -0.80 \\
\hline 2007 & -0.13 & 54 & -0.60 \\
\hline 2008 & 0.25 & 56 & 4.98 \\
\hline 2009 & 0.10 & 50 & 4.30 \\
\hline 2010 & -0.01 & 56 & -0.48 \\
\hline 2011 & -0.03 & 59 & -0.95 \\
\hline 2012 & -0.05 & 60 & -1.13 \\
\hline 2013 & -0.24 & 58 & -4.32 \\
\hline 2014 & -0.20 & 73 & -4.10 \\
\hline
\end{tabular}

The results indicate that, for the full period, there is no evidence for rejecting the null hypothesis of full integration. When examined on an annual basis, it is observed that the same result is obtained for 8 of the 11 years, with rejection clearly occurring in the 2008-2009 period encompassing the financial crisis. 


\section{Testing for country risk premium}

The necessary calculation of expected returns for individual stocks using the Discounted Dividend Model, which are used as values of the dependent variable in regression equations (6) and (7), resulted in the following average values over the 2004-2014 period.

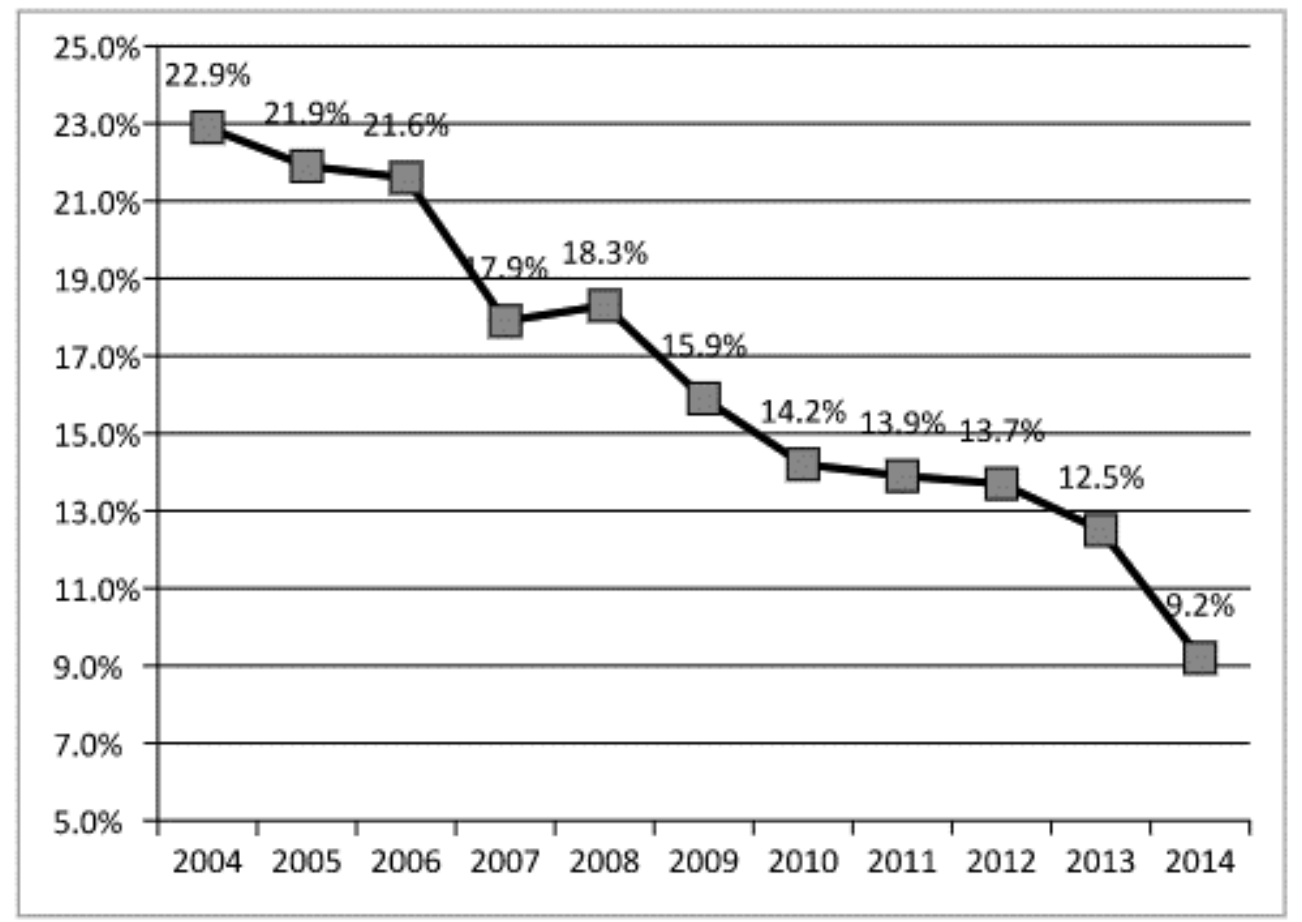

Figure 1. Average Cost of Equity in the Brazilian Market, 2004-2014

Figure 1 indicates that, over the period, there was a reduction in the average cost of equity in the Brazilian market, with the exception of a slight increase in 2008, as would be expected as a reflection of the financial crisis. As was pointed out in the review of literature, a reduction in cost of equity, equivalent to an increase in security prices, accompanies an increase in a particular market's integration into the world market.

The premium for country risk will be considered relevant if we reject the null hypotheses that $\gamma_{2}$ is equal to zero, against the alternative that it is positive.

Although the Hausman test did not lead to the rejection of the null hypothesis that the random effects model would be appropriate (chi-square $=2.8196$, $\mathrm{p}$-value $=0.4026$ ), equation $(6)$ was estimated with the fixed effects model. According to Wooldridge (2008), the assumption that unobserved effects are uncorrelated with the explanatory variables is an exception to the rule, and for this reason the fixed effects model is widely used. In addition, for time-varying explanatory variables, the random effects model is recommended only when the sample is randomly selected. This is not the case in the present paper, in which, for every year, the stocks selected were those included in the $\mathrm{IBrX} 100$ index.

Initially, tests for heteroskedastic and serially correlated errors were performed. The procedure for testing for potentially heteroskedastic and serially correlated errors across panels was based on the use of the xtgls and xtserial commands in $\operatorname{Stata}^{(3)}$.

The results of the likelihood ratio test indicate the presence of heteroskedastic errors across panels $(\operatorname{chi}(2)=13.68, \mathrm{p}$-value $=0.0011)$. However, the Wooldridge test did not lead to the rejection of the null hypothesis of uncorrelated errors $(\mathrm{F}$ stat $=0.358$, $\mathrm{p}$ - value $=0.5631)$. 
The model represented by equation (6) was therefore estimated with the xtgls specification for heteroskedastic panels, and the results obtained are displayed in Table 4.

Table 4

Panel Data Regression with Fixed Effects, 2004-2014, Testing for Country Risk Premium Only. Dependent Variable: Individual Expected Stock Returns

\begin{tabular}{cccc}
\hline Parameter & Estimate & Standard error & p-value \\
\hline$\gamma_{0}$ & 0.1104 & 0.0086 & 0.000 \\
\hline$\gamma_{1}$ & 0.0110 & 0.0042 & 0.009 \\
\hline$\gamma_{2}$ & -0.0002 & 0.0003 & 0.449 \\
\hline & Wald chi $(2)=6.81$ p-value $=0.0332$ & \\
\hline
\end{tabular}

The results in Table 4 indicate that: (a) the significant intercept suggests that additional factors may be required for explaining expected returns, or that the risk-free rate is not adequately measured, as was the case in Fama and MacBeth (1973); (b) the premium for market risk is positive and significant, as would be generally predicted by the Capital Asset Pricing Model; and (c) the premium for country risk is not significant. This confirms our results when testing for the degree of integration of the Brazilian market with the incremental risk measure: country risk premium should not be relevant if the market is sufficiently integrated, since it can be diversified away ${ }^{(4)}$.

\section{Testing for both country and size risk premiums}

As previously mentioned, a common practice, in addition to including a premium for country risk in the estimation of the cost of equity for individual companies, is the inclusion of a premium for size. The expectation seems to be that the equilibrium expected return on the equity of smaller firms should compensate for an additional risk coming from their more limited size.

Using the specification described in equation (7), the test was performed after accounting for both market portfolio and country risk premiums. The relevance of the size factor, in accordance with the usual practice, would be represented by a positive and significant estimate for $\gamma_{3}$ in equation (7).

As described in section Testing for country risk premium, the same tests for the presence of heteroskedastic and serially correlated errors were performed, and the results for the extended model of equation (7) were similar to those for equation (6): LR test statistic $(\operatorname{chi}(2)=8.09$, p-value $=0.0175)$; Wooldridge test: $\mathrm{F}=0.371, \mathrm{p}$-value $=0.5562)^{(5)}$. Equation $(7)$ was then estimated with the xtgls command in Stata, for heteroskedastic panels, and the following results were obtained (see Table 5):

Table 5

Panel Data Regression with Fixed Effects, 2004-2014, Testing for Both Country and Size Risk Premiums. Dependent Variable: Individual Expected Stock Returns

\begin{tabular}{cccc}
\hline Parameter & Estimate & Standard error & p-value \\
\hline$\gamma_{0}$ & 0.1205 & 0.0086 & 0.000 \\
\hline$\gamma_{1}$ & 0.0108 & 0.0041 & 0.008 \\
\hline$\gamma_{2}$ & -0.0001 & 0.0003 & 0.649 \\
\hline$\gamma_{3}$ & -0.0047 & 0.0009 & 0.000 \\
\hline & Wald chi $(2)=34.67 \mathrm{p}$-value $=0.0000$ & \\
\hline
\end{tabular}


When one compares the results from Tables 4 and 5, the following can be said: (a) the significance of the intercept and market risk premium still stands, and the corresponding coefficient values are very similar; (b) country risk continues not to command a significant and especially positive premium; (c) the premium for the size factor is significant, but the result would support the claim that expected returns on the equity of smaller firms should be lower, and not higher, as usually believed and practiced.

\section{Conclusion}

This paper is concerned with verifying the appropriateness of including premiums for both country risk and size in the estimation of the cost of equity for individual firms. Such inclusions are common practice in the Brazilian market, for various purposes: valuation, expected return estimation, regulatory setting of rates of return, incentives to executives in the form of variable compensation, to name only a few, but arguably the most important.

As discussed in the paper, the inclusion of a country risk premium is predicated on the assumption that such a market is not fully integrated to the world market. However, that type of risk would be diversifiable, and hence it should not be priced if the market was fully integrated.

Besides testing the model's implication that the country risk premium is positive and significant, in addition to a premium for market risk proxied by an international index, to reflect the usual practice, the paper tests the significance of a direct measure of market integration, as developed by Keck et al. (1998).

In contrast with previous attempts at testing some version of the CAPM, such as Fama and French (1992), this paper uses expected excess returns implicit in current stock market prices, following Harris et al. (2003).

Both analyses, using annual data for more than 50 firms in the Brazilian market over the 20042014 period lead to negative conclusions regarding the relevance of a premium for country risk. If anything, the results point instead to the validity of using the S\&P 500 index as a proxy for market risk in integrated markets. The results also indicate that the estimated intercept in our version of a two-factor model is positive and significant, suggesting the need for including other risk factors - possibly those empirically determined by Fama and French (1992) - for Brazilian stocks, an avenue for future study.

The inclusion of a third factor (size premium) was also tested, with the results indicating that size premium has a negative and significant relationship with expected returns, in contrast with how this risk factor is dealt with in practice.

\section{Notes}

\footnotetext{
${ }^{1}$ Since the sample size in each year was not large enough, individual stock betas were used, and not portfolios, as in Harris $e t$ al. (2003). According to Claessens, S., Dasgupta, S., \& Glen, J. (1995). The cross section of stock returns - evidence from emerging markets (Policy Research Working Paper Series). Washington, D.C.: The World Bank Publications, the use of panel data and estimation with the fixed effects model, because the data are centered are around their means, tends to attenuate the estimation bias caused by the use of individual stocks.

${ }^{2}$ This is a capitalization-weighted index computed by the BM\&FBovespa for the Brazilian market. It includes the 100 securities with the largest share of trading volume in the preceding 12 months. The capitalization weights are based on the securities' free float.

${ }^{3}$ Wiggins, V., \& Poi, B. (n.d.). Testing for panel-level heteroskedasticity and autocorrelation. Retrieved November 9, 2016, from http://www.stata.com/support/faqs/statistics/panel-level-heteroskedasticity-and-autocorrelation/
} 


\footnotetext{
${ }^{4}$ A test for the null hypothesis of normally distributed errors was also performed with the sktest available in Stata, and that hypothesis was rejected $(p$-value $=0.0000)$. However, this does not detract from our estimation procedure, since our estimator is still unbiased and consistent.

${ }^{5}$ The test for the hypothesis of normally distributed errors led to the rejection of that hypothesis ( $p$-value $=0.000$ ).
}

\section{References}

Bekaert, G., \& Harvey, C. R. (1995). Time-varying world market integration. Journal of Finance, 50(2), 403-409. http://dx.doi.org/10.1111/j.1540-6261.1995.tb04790.x

Bekaert, G., Harvey, C. R., \& Lumsdaine, R. L. (2002). Dating the integration of world equity markets. Journal of Financial Economics, 65(2), 203-247. http://dx.doi.org/10.1016/S0304405X(02)00139-3

Bekaert, G., Harvey, C. R., \& Lundblad, C. T. (2003). Equity market liberalization in emerging markets. Journal of Financial Research, 26(3), 275-299. http://dx.doi.org/10.1111/1475-6803.00059

Elton, E. J. (1999). Expected return, realized return, and asset pricing tests. Journal of Finance, 54(4), 1199-1220. http://dx.doi.org/10.2469/dig.v30.n1.604

Elton, E. J., Gruber, M. J., Brown, S. J., \& Goetzmann, W. N. (2006). Modern portfolio theory and investment analysis (8th ed.). New York: Wiley.

Errunza, V. R., \& Miller, D. P. (2000). Market segmentation and the cost of capital in international equity markets. Journal of Financial and Quantitative Analysis, 35(4), 577-598. http://dx.doi.org/10.2307/2676256

Fama, E. F., \& French, K. R. (1992). Cross section of expected stock returns. Journal of Finance, 47(2), 427-465. http://dx.doi.org/10.1111/j.1540-6261.1992.tb04398.x

Fama, E. F., \& French, K. R. (2002). The equity premium. Journal of Finance, 57(2), 637-659. http://dx.doi.org/10.1111/1540-6261.00437

Fama, E. F., \& French, K. R. (2015). A five-factor asset pricing model. Journal of Financial Economics, 116(1), 1-22. http://dx.doi.org/10.1016/j.jfineco.2014.10.010

Fama, E. F., \& Macbeth, J. D. (1973). Risk, return and equilibrium: empirical tests. Journal of Political Economy, 81(3), 607-636. http://dx.doi.org/10.1086/260061

Fuenzalida, D., \& Mongrut, S. A. (2010). Estimation of discount rates in Latin America: empirical evidences and challenges. Journal of Economics, Finance and Administrative Science, 15(28), 7-23.

Gordon, M. J. (1959). Dividends, earnings and stock prices. The Review of Economics and Statistics, 41(2), 99-105. http://dx.doi.org/10.2307/1927792

Harris, R. F., Marston, F. C., Mishra, D. R., \& O’Brien, T. (2003). Ex ante cost of equity estimates for US stocks: global versus domestic CAPM. Financial Management, 32(3), 51-66. http://dx.doi.org/10.2139/ssrn.322680

Harvey, C. R. (1995). Predictable risk and returns in emerging markets. Review of Financial Studies, 8(3), 773-816. https://doi.org/10.1093/rfs/8.3.773

Harvey, C. R. (2005). 12 ways to calculate the international cost of capital. Cambridge, MA: National Bureau of Economic Research. 
Henry, P. B. (2000). Stock market liberalization, economic reform, and emerging market equity prices. Journal of Finance, 55(2), 529-564. http://dx.doi.org/10.1111/0022-1082.00219

Huberman, G. (2001). Familiarity breeds investment. The Review of Financial Studies, 14(3), 659-680. https://doi.org/10.1093/rfs/14.3.659

Keck, T., Levengood, E., \& Longfield, A. (1998). Using discounted cash flow analysis in an international setting: a survey of issues in modeling the cost of capital. Journal of Applied Corporate Finance, 11(3), 82-99. http://dx.doi.org/10.1111/j.1745-6622.1998.tb00505.x

Lintner, J. (1965). The valuation of risk assets and the selection of risky investments in stock portfolios and capital budgets. The Review of Economics and Statistics, 47(1), 13-37. http://dx.doi.org/10.2307/1924119.

Mariscal, J. O., \& Lee, R. M. (1993, June 18). The valuation of Mexican stocks: an extension of the capital asset pricing model to emerging markets. New York: Goldman Sachs Investment Research. Retrieved from https://faculty.fuqua.duke.edu/ charvey/Teaching/BA456_2006/GS_The_valuation_of_mexica n_stocks.pdf

Mossin, J. (1966). Equilibrium in a capital asset market. Econometrica, 34(4), 768-783. 0012http://dx.doi.org/9682(196610)34:4<768:EIACAM>2.0.CO;2-3

Pereiro, L. E. (2001). The valuation of closely-held companies in Latin America. Emerging Markets Review, 2(4), 330-370. http://dx.doi.org/10.1016/S1566-0141(01)00024-3

Sanvicente, A. Z. (2015). Relevância de prêmio por risco país no custo de capital das empresas. Revista de Administração Contemporânea [Edição Especial], 19, 38-52. Retrieved from http://www.scielo.br/pdf/rac/v19nspe/1415-6555-rac-19-spe-00038.pdf.

http://dx.doi.org/10.1590/1982-7849rac2015140097

Sanvicente, A. Z., \& Carvalho, M. R. (2013). Determinants of the implied equity risk premium [Insper Working Paper WPE: 281/2012]. Insper, São Paulo, SP, Brasil. Retrieved from https://www.insper.edu.br/wp-content/uploads/2012/11/2012_wpe281.pdf

Sanvicente, A. Z., \& Minardi, A. M. A. F. (1999, 30 abril). Determinação do custo de capital do acionista no Brasil [FINANCELAB WORKING PAPER - FLWP - 12 - 1999]. Ibmec São Paulo, São Paulo, SP, Brasil. $\quad$ Retrieved from http://epge.fgv.br/we/Graduacao/AvaliacaoDeEmpresas/2007?action=AttachFile\&do=get\&targ et=custodecapitalnobrasil2.pdf

Sercu, P., \& Vanpée, R. (2007, August 8). Home bias in international equity portfolios: a review [Report AFI 0710]. Department of Accountancy, Finance and Insurance, Katholieke Universiteit Leuven, Belgium. Retrieved from https://core.ac.uk/download/pdf/6468770.pdf

Sharpe, W. F. (1964). Capital asset prices: a theory of market equilibrium. Journal of Finance, 19(3), 425-442. Retrieved from http://onlinelibrary.wiley.com/doi/10.1111/j.15406261.1964.tb02865.x/pdf

Solnik, B. H. (1974). An equilibrium model of the international capital market. Journal of Economic Theory, 8(4), 500-524.

Stulz, R. M. (1995). Globalization of capital markets and the cost of capital: the case of Nestlé. Journal of Applied Corporate Finance, 8(3), 30-38. http://dx.doi.org/10.1111/j.17456622.1995.tb00634.x

Stulz, R. M. (1999). Globalization, corporate finance and the cost of capital. Journal of Applied Corporate Finance, 12(3), 8-25. http://dx.doi.org/10.1111/j.1745-6622.1999.tb00027.x 
Wooldridge, J. M. (2008). Introductory econometrics: a modern approach (4th ed.). Mason, Ohio: South-Western Cengage Learning.

Zenner, M., Hill, S., Clark, J., \& Mago, N. (2008). The most important number in finance - the quest for the market risk premium. New York: JP Morgan Chase.

\section{Authors' Profiles}

Antonio Zoratto Sanvicente

Rua Itapeva, 474, 01332-000, São Paulo, SP, Brazil. E-mail address: antonio.sanvicente@ fgv.br

Hsia Hua Sheng

Av. Nove de Julho, 2029, Bela Vista, 01313-902, São Paulo, SP, Brazil. E-mail address: Hsia.sheng @fgv.br

Luiz Felipe Poli Guanais

Rua Itapeva, 474, 01332-000, São Paulo, SP, Brazil. E-mail address: fguanais@ hotmail.com 